\title{
SIMULASI CHARGE DISCHARGE MODEL BATERAI LEAD ACID
}

\author{
RAHMA DINI BARKAH *, SAHRUL HIDAYAT \\ Departemen Fisika Fakultas MIPA Universitas Padjadjaran, \\ Jl. Raya Bandung-Sumedang Km 21,Jatinangor 45363 \\ *email : dinibarkah43@gmail.com
}

\begin{abstract}
Abstrak. Telah dilakukan simulasi charge-discharge model baterai lead acid dengan bantuan software Comsol. Pada penelitian ini dilakukan beberapa variasi arus pada proses charge dan discharge. Pada proses charge arus yang divariasikan sebesar 1/30C, 1/25C, 1/20C 1/10C, 1/5C, 1/2C dan 1C sedangkan pada proses discharge variasi arus pembebanannya sebesar 1/20C, 1/10C, 1/5C, 1/2C, 1C, 2C, 5C, 10C dan 20C. Berdasarkan hasil penelitian yang telah dilakukan diperoleh kapasitas maksimum pada proses charge sebesar 897 Amper.secon pada arus pengisian 1/2C. Sedangkan kapasitas maksimum pada proses discharge sebesar 770 Ampere.secon pada arus pembebanan 1/5C. Disipasi daya baterai semakin besar seiring dengan semakin besarnya arus pengisian ataupun arus pembebanan. Berdasarkan hasil simulasi diperoleh efisiensi maksimum model baterai lead acid adalah sebesar $85,84 \%$.
\end{abstract}

Kata kunci: lead acid, simulasi, model baterai, charge-discharge

\begin{abstract}
We have studied the characteristics of charge-discharge of lead acid battery model. In our research, charge and discharge current was varied to study the correlation between charge-discharge current and the efficiency of battery. In our simulation, the charge current varied by $1 / 30 \mathrm{C}, 1 / 25 \mathrm{C}, 1 / 20 \mathrm{C}, 1 / 10 \mathrm{C}, 1 / 5 \mathrm{C}, 1 / 2 \mathrm{C}$ and $1 \mathrm{C}$ while the discharge current varied by $1 / 20 \mathrm{C}, 1 / 10 \mathrm{C}, 1 / 5 \mathrm{C}, 1 / 2 \mathrm{C}, 1 \mathrm{C}, 2 \mathrm{C}, 5 \mathrm{C}, 10 \mathrm{C}$ and $20 \mathrm{C}$. The results of our research obtain the maximum capacity of charging is 897 Ampere.seconds at the charging current of $1 / 2 \mathrm{C}$. While the maximum capacity of discharge process is 770 Ampere.seconds at $1 / 5 \mathrm{C}$ discharge current. The power dissipation of battery is goes up correspond to increasing charging and discharge currents. Our simulation obtains the maximum efficiency of lead acid battery is $85.84 \%$.
\end{abstract}

Keywords: lead acid, simulation, battery model, charge-discharge

\section{Pendahuluan}

Baterai lead acid merupakan salah satu dari jenis baterai sekunder yang dapat diisi ulang. Baterai lead acid menggunakan $\mathrm{PbO}_{2}$ (Lead Peroxide) sebagai katoda, $\mathrm{Pb}$ (lead sponge) sebagai anoda dan $\mathrm{H}_{2} \mathrm{SO}_{4}$ (sulfuric acid) sebagai elektrolit. Baterai lead acid memiliki beberapa kelebihan seperti biaya perawatan yang lebih murah dibandingkan baterai sekunder lainnya sehingga cocok untuk penggunaan industri, tersedia dalam kapasitas yang besar, tingkat performa yang tinggi dan kinerja yang baik saat suhu rendah maupun tinggi. Namun demikian, baterai lead acid memiliki beberapa kelemahan seperti memerlukan waktu yang lama untuk proses pengisian, siklus hidup relatif rendah dan saat penyimpanan jangka panjang akan mengalami self discharge [1].

Baterai lead acid yang terisi penuh memiliki kepadatan asam sekitar 1,24 kg/liter pada temperatur $25^{\circ} \mathrm{C}$. Kepadatan asam akan berubah-ubah sesuai suhu dan 
keadaan muatan dari baterai [2]. Baterai lead acid beroperasi dengan reaksi reduksi dan oksidasi dari material anoda dan katoda. Saat baterai melepaskan muatan maka material aktif pada elektroda bereaksi dengan elektrolit membentuk $\mathrm{PbSO}_{4}$ dan air. Sedangkan saat pengisian muatan maka $\mathrm{PbSO}_{4}$ berubah kembali menjadi $\mathrm{PbO} 2$ pada elektroda positif dan negatif, dan ion sulfat kembali menjadi larutan elektrolit membentuk asam sulfat [2]. Reaksi sel dasar dalam baterai lead acid sebagai berikut:

Reaksi pada saat pengosongan baterai adalah:

$$
\mathrm{Pb}+\mathrm{PbO}_{2}+2 \mathrm{H}_{2} \mathrm{SO}_{4} \rightarrow 2 \mathrm{PbSO}_{4}+2 \mathrm{H}_{2} \mathrm{O}
$$

a. Reaksi pada elektroda negatif (anoda)

$$
\mathrm{Pb}+\mathrm{HSO}_{4}^{-} \rightarrow \mathrm{PbSO}_{4}+\mathrm{H}^{+}+2 \mathrm{e}
$$

b. Pada elektroda positif (katoda)

$$
\mathrm{PbO}_{2}+\mathrm{HSO}_{4}^{-}+3 \mathrm{H}^{+}+2 \mathrm{e} \rightarrow \mathrm{PbSO}_{4}+2 \mathrm{H}_{2} \mathrm{O}
$$

Reaksi pada pengisian baterai

$$
2 \mathrm{PbSO}_{4}+2 \mathrm{H}_{2} \mathrm{O} \rightarrow \mathrm{Pb}+\mathrm{PbO}_{2}+2 \mathrm{H}_{2} \mathrm{SO}_{4}
$$

Pada proses pengisian terjadi reaksi:

a. Pada elektroda negatif (anoda)

$$
\mathrm{PbSO}_{4}+\mathrm{H}^{+}+2 \mathrm{e}^{-} \rightarrow \mathrm{Pb}+\mathrm{HSO}_{4}^{-}
$$

b. Pada elektroda positif (katoda)

$$
\mathrm{PbSO}_{4}+2 \mathrm{H}_{2} \mathrm{O} \rightarrow \mathrm{PbO}_{2}+\mathrm{HSO}_{4}^{-}+3 \mathrm{H}^{+}+2 \mathrm{e}^{-}
$$

Tegangan nominal dari sell lead acid sekitar 2 Volt. Tegangan pada rangkaian terbuka merupakan fungsi langsung dari konsentrasi elektrolit mulai dari $2,125 \mathrm{~V}$ untuk sel dengan berat jenis 1,28 dan elektrolit 2,05 V untuk berat jenis 1,21. Tegangan cut-off pada saat proses pengosongan berkisar $1,75 \mathrm{~V}$ per sel tetapi bisa mencapai $1 \mathrm{~V}$ per sel pada tingkat debit yang sangat tinggi pada suhu rendah [1].

Baterai lead acid akan menunjukkan self discharge antara 1\% dan 5\% setiap bulannya pada suhu 200C. Reaksi pelepasan ini melibatkan dekomposisi air untuk membentuk hidrogen dan oksigen. Tingkat self discharge akan naik seiring dengan pertambahan suhu. Jika proses dilanjutkan tanpa proses pengisian, maka akan berlanjut dengan pelepasan lead sulfat secara progresif dan baterai akan mengalami drop capacity dan tidak bisa digunakan lagi [1]. Berikut karakteristik dari baterai lead acid ditampilkan pada Tabel 1.

Tabel 1. Karakteristik fisis dari Baterai Lead Acid [3]

\begin{tabular}{l|l}
\hline Parameter Fisis & Nilai \\
\hline Nominal Cell voltage, V & 2.0 \\
Specific energy (Wh/kg) & $35-40$ \\
Energy density (Wh/L) & $70-90$ \\
Charge retention at $20^{\circ} \mathrm{C}$ ( shel life) & $6-9$ months \\
Overall service life & 15 years \\
Cycle life, cycle & $1500-5000$ \\
Operating temperature, oC & -40 to 60 \\
\hline
\end{tabular}




\section{Metode Penelitian}

Objek dalam penelitian ini adalah baterai Lead Acid yang dimodelkan. Dalam penelitian ini data yang diperlukan adalah ukuran geometri, material bahan dan arus yang diberikan pada baterai lead acid yang digunakan untuk modelling baterai lead acid. Batasan model yang digunakan pada pemodelan ini yaitu baterai lead acid dengan 1 sel dan penyelesaian model menggunakan program Comsol Multiphysics. Penentuan batasan model ini bertujuan untuk menyederhanakan pemodelan dengan memasukkan asumsi-asumsi yang telah ditetapkan. Ruang geometri yang digunakan pada model baterai lead acid yaitu 1 dimensi dan 2 dimensi. Ukuran dari geometri yang digunakan sesuai dengan baterai lead acid yang sebenarnya. Ukuran geometri yang digunakan diperlihatkan pada Tabel 2.

Tabel 2. Ukuran geometri baterai lead acid

\begin{tabular}{llllll}
\hline Geometri & & Katoda & Reservoir & Separator & Anoda \\
\hline $\mathbf{1}$ dimensi & Ketebalan & $0,7 \mathrm{~mm}$ & $1,76 \mathrm{~mm}$ & $0.06 \mathrm{~mm}$ & $0,75 \mathrm{~mm}$ \\
$\mathbf{2}$ dimensi & Ketebalan & $0,2 \mathrm{~cm}$ & $0,3 \mathrm{~cm}$ & $0,05 \mathrm{~cm}$ & $0,2 \mathrm{~cm}$ \\
& Lebar & $10 \mathrm{~cm}$ & $10 \mathrm{~cm}$ & $10 \mathrm{~cm}$ & $10 \mathrm{~cm}$ \\
& & & & \\
\hline
\end{tabular}

Persamaan yang digunakan untuk melakukan pemodelan baterai lead acid ini yaitu persamaan difusi muatan sebagai berikut [4]:

$$
\begin{array}{ll}
\frac{\partial c_{l}}{\partial t}+\nabla \cdot\left(-D_{l} \nabla c_{l}\right)+\mathrm{u} . & \nabla c_{l}=\mathrm{R}_{\mathrm{l}, \mathrm{src}} \\
\nabla . \mathrm{i}_{\mathrm{l}}=\mathrm{Q}_{\mathrm{l}} & ; \nabla \cdot \mathrm{i}_{\mathrm{s}}=\mathrm{Q}_{\mathrm{s}} \\
\mathrm{i}_{\mathrm{s}}=\epsilon^{\text {exm }}\left(-\sigma_{s} \nabla \emptyset_{s}\right) & ; \mathrm{i}_{\mathrm{l}}=\left(-\sigma_{l} \nabla \emptyset_{l}\right)+\left(\frac{\sigma_{l} R T}{F}\right)\left(1-2 \mathrm{t}_{+}\right) \nabla \ln c_{l} \\
\mathrm{~N}_{\mathrm{l}}=-D_{l} \nabla c_{l}+\mathrm{u} c_{l} &
\end{array}
$$

Dengan:

$\mathrm{N}_{1}=$ total fluks elektrolit $\left(\mathrm{mol} / \mathrm{m}_{2} \mathrm{~s}\right)$

$D_{l}=$ koefisien difusi elektrolit $\left(\mathrm{m}_{2} / \mathrm{s}\right)$

$F=$ konstan faraday $(\mathrm{C} / \mathrm{mol})$

$\emptyset_{l}=$ tegangan elektrolit $; \emptyset_{s}=$ tegangan elektroda

$u=$ kecepatan $(\mathrm{m} / \mathrm{s})$

$c_{l}=$ konsentrasi elektrolit $\left(\mathrm{mol} / \mathrm{m}_{3}\right)$

$t=$ waktu (s)

$\mathrm{Q}^{1}=$ sumber muatan dari elektrolit; $\mathrm{Q}_{\mathrm{s}}=$ sumber muatan dari elektroda

$\mathrm{i}^{1}=$ distribusi arus di elektrolit $\left(\mathrm{A} / \mathrm{m}^{2}\right)$

$\mathrm{i}^{\mathrm{s}}=$ distribusi arus di elektrolit $\left(\mathrm{A} / \mathrm{m}^{2}\right)$

$\mathrm{R}=$ konstanta gas ideal

\section{Hasil dan Pembahasan}

Pengujian proses charge pada baterai lead acid dilakukan dengan metode arus konstan untuk 1 siklus. Pada penelitian ini divariasikan arus pengisian yaitu sebesar 
1/30 C, 1/25 C, 1/20 C, 1/10 C, 1/5 C, 1/2 C dan $1 \mathrm{C}$. Hasil pengujian ini ditunjukkan pada Gambar 1.

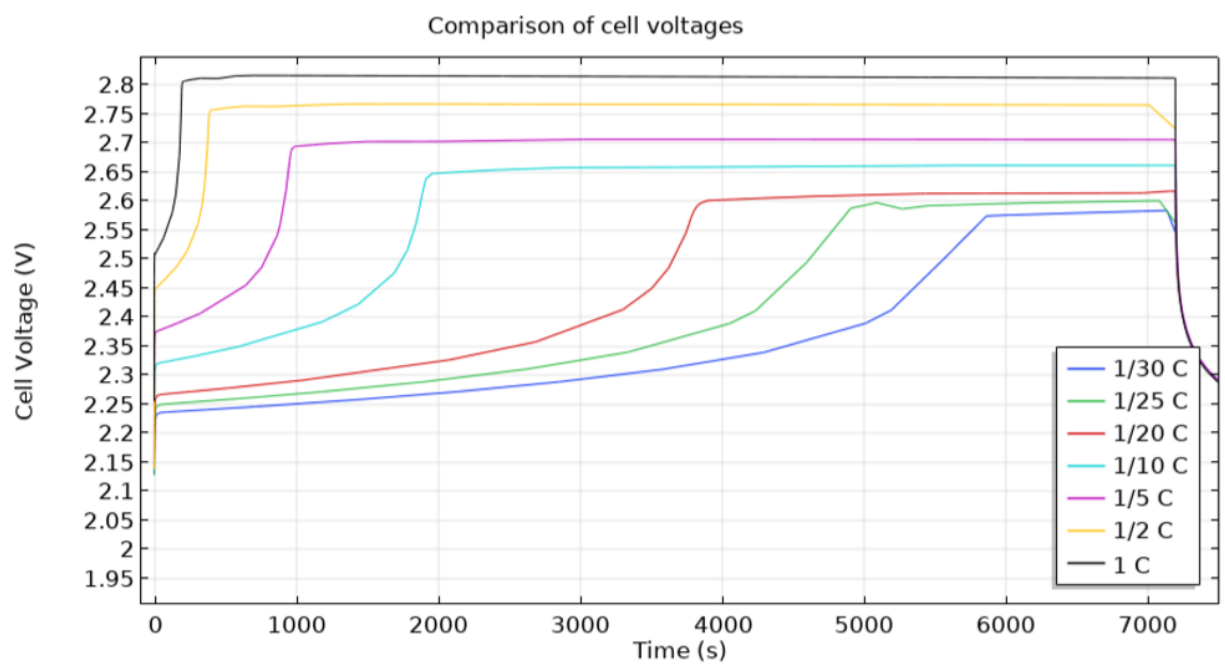

Gambar 1. Grafik tegangan terhadap waktu pada proses charge

Pada Gambar 1 dapat dilihat bahwa variasi arus yang diberikan pada saat charge mempengaruhi tegangan awal pengisian dimana saat arus yang diberikan semakin besar maka tegangan awal pengisian baterai akan semakin besar juga. Hal ini dikarenakan muatan dipaksa masuk kedalam sel dimana muatan itu sebanding dengan arus dan waktu. Muatan masuk yang semakin besar akan menyebabkan perbedaan tegangan antara katoda dan anoda membesar sehingga mengakibatkan tegangan tertutup di awal pengisian berbeda. Lamanya waktu pengisian dipengaruhi oleh besarnya arus pengisian yang diberikan, semakin besar arus pengisiannya maka waktu yang dibutuhkan untuk pengisian akan semakin cepat. Variasi arus pengisian juga mempengaruhi proses redoks, ketika arus pengisian yang diberikan semakin kecil maka akan menyebabkan jumlah proses reaksi redoks pada kedua elektron semakin lambat dan sedikit.

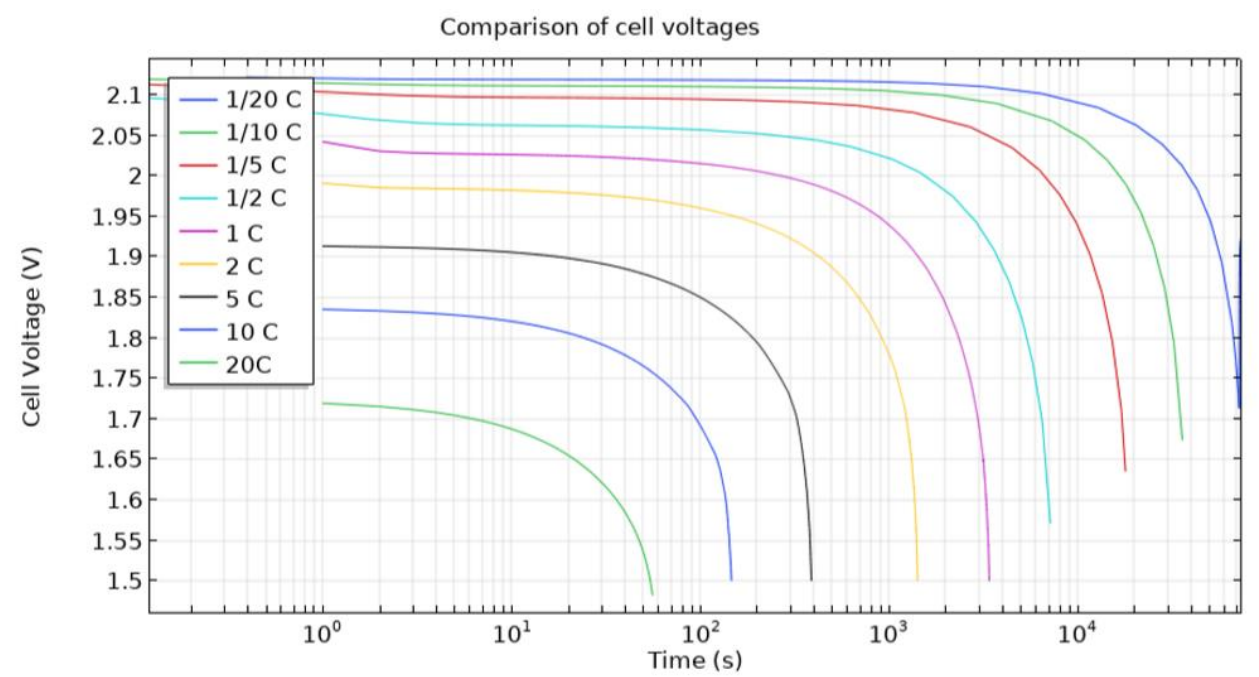

Gambar 2. Grafik perbandingan tegangan sel terhadap waktu pengosongan 
Pengujian proses discharge pada baterai lead acid dilakukan dengan metode arus konstan untuk 1 siklus. Pada penelitian ini diberikan variasi arus pembebanan yaitu sebesar 1/20C, 1/10C, 1/5C, 1/2C, 1C, 2C, 5C, 10C dan 20C. Hasil pengujian ini ditunjukkan pada Gambar 2.

Pada Gambar 2 dapat dilihat bahwa terjadi penurunan tegangan terhadap waktu yang disebabkan dari variasi arus pembebanan yang diberikan, terlihat bahwa grafik yang dihasilkan memiliki bentuk yang sama yaitu menurun dengan konstan di awal dan drop di akhir pengosongan. Semakin besar arus pembebanan yang diberikan maka waktu yang dibutuhkan untuk mencapai batas minimum tegangan operasional baterai akan semakin cepat juga. Lamanya durasi waktu pengosongan ini bergantung pada muatan yang tersimpan dan arus listrik yang diberikan. Lamanya durasi saat charge dan discharge berbeda karena saat proses discharge jumlah reaksi redoks lebih sedikit dibandingkan dengan jumlah reaksi redoks saat proses charge hal ini disebabkan karena tidak semua muatannya berpindah ke elektroda. Variasi arus pembebanan juga mempengaruhi proses redoks, ketika arus pengosongan yang diberikan semakin kecil maka akan menyebabkan jumlah proses reaksi redoks pada kedua elektron semakin lambat dan sedikit.

Kapasitas baterai dapat ditentukan dari proses charge dan discharge. Untuk mengetahui kapasitas baterai dapat dilihat dari grafik tegangan terhadap waktu dengan memvariasikan arus saat charge dan discharge. Berdasarkan grafik pada Gambar 1 dapat dihitung kapasitas baterai pada saat diisi seperti dipelihatkan pada Tabel 3.

Tabel 3. Kapasitas baterai lead acid pada saat charge

\begin{tabular}{cccccc}
\hline I (A) & t0 (s) & ta (s) & ta-t0 (s) & $\begin{array}{c}\text { Kapasitas } \\
(\mathbf{A h})\end{array}$ & Efisiensi (\%) \\
\hline $1 / 30 \mathrm{C}$ & 0 & 7141 & 7141 & 238.03 & 26.54 \\
$1 / 25 \mathrm{C}$ & 0 & 6187 & 6187 & 247.48 & 27.59 \\
$1 / 20 \mathrm{C}$ & 0 & 7197 & 7197 & 359.85 & 80.25 \\
$1 / 10 \mathrm{C}$ & 0 & 7198 & 7198 & 719.80 & 80.25 \\
$1 / 5 \mathrm{C}$ & 0 & 4053 & 4053 & 810.60 & 810.60 \\
$1 / 2 \mathrm{C}$ & 0 & 1794 & 1794 & 897.00 & 100.00 \\
$1 \mathrm{C}$ & 0 & 701 & 701 & 701.00 & 78.15 \\
\hline
\end{tabular}

Pada Tabel 3 terlihat kapasitas baterai yang dihasilkan saat proses charge. Ketika arus pengisian semakin besar maka kapasitas baterai yang tersimpan juga akan semakin besar, hal ini karena ketika pengisian muatan-muatan akan mengalir ke dalam baterai. Terlihat pada tabel 1 kapasitas tertinggi yaitu pada arus $1 / 2 \mathrm{C}$, namun ketika diberikan arus pengisian $1 \mathrm{C}$, kapasitas yang dihasilkan tidak terlalu besar, ini dikarenakan arus pengisian yang digunakan terlalu besar, ketika arus yang digunakan terlalu besar maka tidak semua muatan masuk ke dalam baterai. 
Tabel 4. Kapasitas baterai lead acid pada saat discharge

\begin{tabular}{cccccc}
\hline I (A) & t0 (s) & ta (s) & ta-to (s) & $\begin{array}{c}\text { Kapasitas } \\
(\mathbf{A h})\end{array}$ & Efisiensi (\%) \\
\hline $1 / 30 \mathrm{C}$ & 0 & 8800 & 8800 & 440 & 57.14 \\
$1 / 10 \mathrm{C}$ & 0 & 6800 & 6800 & 680 & 88.31 \\
$1 / 5 \mathrm{C}$ & 0 & 3850 & 3850 & 770 & 100.00 \\
$1 / 2 \mathrm{C}$ & 0 & 1400 & 1400 & 700 & 90,90 \\
$1 \mathrm{C}$ & 0 & 680 & 679 & 679 & 88.18 \\
$2 \mathrm{C}$ & 0 & 335 & 334 & 668 & 86.75 \\
$5 \mathrm{C}$ & 0 & 110 & 109 & 545 & 70.78 \\
$10 \mathrm{C}$ & 0 & 40 & 39 & 390 & 50.65 \\
$20 \mathrm{C}$ & 0 & 17.8 & 16.8 & 336 & 43.64 \\
\hline
\end{tabular}

Pada Tabel 4. terlihat kapasitas baterai yang dihasilkan saat proses discharge. Ketika arus pengosongan yang diberikan semakin besar maka kapasitas baterai semakin rendah, hal ini karena tingkat pelepasan muatannya semakin besar. Pada tabel 3 kapasitas optimum untuk melakukan discharge yaitu pada arus pembebanan 1/5 C, namun jika arus pembebanan yang diberikan terlalu kecil juga tidak baik, karena dapat menyebaban self dischare pada baterai. Dari data hasil kapasitas saat proses charge dan discharge ini dapat dihasilkan efisiensi maksimum pada model baterai lead acid dengan menggunakan persamaan:

$$
\% \text { efisiensi }=\frac{\text { kapasitas discharge }}{\text { kapasitas charge }} \times 100 \%
$$

Dengan menggunakan persamaan tersebut didapatkan efisiensi baterai maksimum sebesar $85,84 \%$.

\section{Kesimpulan}

Pada saat proses charge, kapasitas baterai lead acid akan semakin naik ketika arus yang diberikan semakin besar, namun saat diberikan arus $1 \mathrm{C}$, kapasitas baterainya lebih kecil dibandingkan ketika diberikan arus 1/2 C. Kapasitas maksimum baterai lead acid yang dihasilkan saat proses charge adalah pada arus pengisian 1/2 C. Pada proses discharge, kapasitas baterai akan semakin menurun ketika diberikan arus yang semakin besar, namun saat diberikan arus pembebanan 1/20 C dan 1/10 C kapasitas baterainya lebih kecil dibandingkan ketika diberikan arus 1/5 C. Kapasitas terbesar saat arus pembebanan 1/5 C. Efisiensi baterai lead acid yang dihasilkan yaitu sebesar $85,84 \%$. 


\section{Daftar Pustaka}

1. A.J. Salkind et al. 2002. Handbook of Batteries.

2. Prisma, Alief, B. Segara, D. C. Riawan, H. Suryoatmojo, Monitoring Kinerja Baterai Berbasis Timbal Untuk Sistem Photovoltaic. Vol 1 No. 1 (2013) 1-6.

3. D. H. Collins, 1985, Modern Batteries. An Introduction to Electrochemical Power Sources, Journal of Power Sources Vol. 14 No. 4 (1985) 331-32.

4. Whittingham, M. Stanley, R. F. Savinell, T. Zawodzinski, Introduction: Batteries and Fuel Cells, Chemical Reviews Vol. 104 No. 10 (2004) 42-44 